\title{
Bacteriological Study of Ballast Water at Tanjung Emas Port, Semarang
}

\author{
Iksiroh El Husna1,2*, Sutrisno Anggoro ${ }^{3}$, Henna Rya Abdurachim ${ }^{1,4}$, Subagiyo $^{5}$, \\ Mostafa Imhmed Ighwerb6 \\ ${ }^{1}$ Environmental Doctoral Study Program, School of Graduate Study, Universitas Diponegoro \\ Jl. Prof. H. Soedarto, SH, Tembalang, Semarang, Central Java, 50275 Indonesia \\ 2Nautical Study Program, Semarang Merchant Marine Polytechnic \\ Jl. Singosari Raya No.2A, Wonodri, Semarang, Jawa Tengah 50242 Indonesia \\ ${ }^{3}$ Aquatic Resources Department, Faculty of Fisheries and Marine Sciences, Universitas Diponegoro \\ ${ }^{4}$ Faculty of Medicine, Universitas Diponegoro \\ ${ }^{5}$ Marine Science Department, Faculty of Fisheries and Marine Science, Universitas Diponegoro \\ Jl. Prof. H. Soedarto, SH, Tembalang, Semarang, Central Java, 50275 Indonesia \\ ${ }^{6}$ Faculty of Marine Resources, Asmarya Islamic University \\ Environment Street, Zliten, Libya \\ Email: iksirmahfudz@yahoo.co.id
}

\begin{abstract}
The D-2 Ballast Water Management Convention standard regulates the requirements for the disposal of ballast water, which must not contain pathogenic bacteria, which are harmful to health and pollute the environment and the sustainability of local ecosystems. Tanjung Emas was chosen because it is one of the busiest ports in Indonesia to serve domestic shipping. In addition, there has never been a study examining the composition of bacteria carried through ballast water at the port of Tanjung Emas. This study aims to determine the content of pathogenic bacteria carried by the ballast water of ships docked at Tanjung Emas Port compared to the waters around the disposal and river flows around Tanjung Emas Port, Semarang. The samples were taken from 4 ships, 5 waters, and 2 rivers in Tanjung Emas area. The samples were analyzed biochemically to obtain the morphology of the bacteria present. The results showed that ballast water from the ships (KVOG, KMPS, and M) contains pathogenic bacteria: V. cholerae, E. coli, enterococci, S. typhii, S. desenteriae, Klebsiella, S. epidermidis, B. subtilis, and Actinobacteria. All types of that bacteria were also found in the Tanjung Emas waters except Actinobacteria. For three bacteria i.e. $V$. cholerae, E. coli, and enterococci whose levels exceed the threshold required by the BWM Convention and have the potential to pollute the Tanjung Emas environment. The water from the river did not contribute to the presence of $\checkmark$. cholerae bacteria in port waters, so the ballast water must be treated before being disposed of.
\end{abstract}

Keywords: Environmental, Tanjung Emas Port, Semarang, Pathogen Bacteria, Ballast water

\section{Introduction}

Ships are the preferred mode of transportation for transporting export-import products, due to their large carrying capacity. Therefore, in world trade, which has a high economic value, $80 \%$ uses ships as a means of transportation (Erga et al., 2018; Emami et al., 2012). Ships need balance when sailing, both in a loaded and unloaded state. In the past, sand/cement was used as ballast. Currently, as a ballast, water is used which is known as ballast water. For the ship to be able to sail without a load, the ship will carry ballast water as a counterweight to maintain stability while sailing. Ballast water is taken from the port of departure which is not known to be clean. Whatever is in the water in the port will go into the ballast tank and be carried around the world until then to the port of destination.
The ballast water will be discharged at the port of destination when the ship is loading (Ballast Water Fact Sheets, 2005. Ballast Water Management, 2006). Emami et al. (2012) predicts that there are more than 3-5 billion tons of ballast water per year moving around the world. In fact, according to Vidas et al. (2011), there are 2-12 billion tons of ballast water carrying 4,000 to 7,000 species that are carried around throughout the world's oceans (David, 2015; Davidson and Simkanin; WGITMO, 2015; David and Gollasch, 2015; Ojaveer et al., 2016). Foreign species present in ballast water are then disposed of in a new environment, considering the world's shipping fleet there are assumption that 3.000-7.000 different species are transit with ships on daily basis (Carlton and Geller, 1993; Gollasch, 1996; Carlton, 2001). Thus will cause invasive species that have been discovered more than 850 
species (Hayes and Sliwa, 2003), and change the structure of the original flora and fauna ecosystem (Putra et al., 2021). This will cause irreversible ecological changes. Besides that, it will also cause health problems in humans and environmental health if there are pathogenic bacteria that will cause economic losses (Cohen et al., 2012). The results of research by El-Husna et al. (2017) found pathogenic bacteria in ballast water discharged at the Indonesian port of Cilacap which pollutes the coastal environment.

The International Maritime Organization (IMO) as a specialized agency of the United Nations has responsibility for the safety and security of all shipping activities and also the prevention of pollution at sea caused by activities onboard ships. With this responsibility, IMO regulates all matters relating to ballast water by issuing the rules for the Ballast Water Management Convention (BWM Convention). BWM Convention with its official title "The International Convention for the Control and Management of Ships Ballast Water and Sediments". Because the BWM Convention has been enforced (Entry into force) since September 8, 2017, all provisions contained in it are binding and must be followed by all IMO member countries. This convention requires every ship to have a Ballast Water Treatment System which functions to control and treat ballast water to kill the species in the ballast water. Following accordance with the provisions, the ship must meet the ballast water management standard (standard D-2) which regulates the ballast water treatment system. According to the D-2 standard, the ballast water to be discharged must meet bacterial standards. This standard stipulates that the content of toxicogenic Vibrio cholerae bacteria is $<1$ CFU.100 ml-1 of water. For Escherichia coli bacteria $<250 \mathrm{cfu} .100 \mathrm{ml}^{-1}$ of water and for intestinal enterococci $<100 \mathrm{cfu} .100 \mathrm{ml}^{-}$ ${ }^{1}$ of ballast water. Many studies have been conducted to determine the content of pathogenic bacteria in ballast water such as V. cholerae and E. coli (Ruiz et al., 2000; Drake et al., 2001; Joachimsthal et al., 2004; Burkholder et al., 2007; Seiden et al., 2011).

In this study, samples were taken from ballast water on ships that docked at Tanjung Emas Port, sea waters around ballast water disposal, and rivers around Tanjung Emas Port, Semarang. Tanjung Emas was chosen because it is one of the busiest ports in Indonesia to serve domestic shipping. In addition, there has never been a study examining the composition of bacteria carried through ballast water at the port of Tanjung Emas. This study aims to determine the content of pathogenic bacteria carried by the ballast water of ships docked at Tanjung Emas Port compared to the waters around the disposal and river flows around Tanjung Emas Port, Semarang.

\section{Materials and Methods}

This research was conducted from January to May 2021. Ballast water samples were taken from a ship docked at Tanjung Emas Port, Semarang, Central Java, Indonesia. These ships are domestic passenger and freight ships that sail between islands such as Java, Kalimantan, Sumatra, and Sulawesi. Ballast water samples were taken from 4 different ships that did not treat the ballast water, each ship was assigned a sample code of KVOG, KMOA, KMPS, and $M$. Apart from ship ballast water, water samples were also taken from the water environment around the port, i.e., the waters of P1, P2, P3, and P4. In addition, water samples were taken from the Banger River (S1) and the Baru River (S2) which empties into the Tanjung Emas port, Semarang (Figure 1.). Water samples were taken using a $250 \mathrm{ml}$ sterile bucket bottle, then the water sample was put into a $50 \mathrm{ml}$ sterile tube. Samples that have been put into the tube are then taken to the laboratory for further analysis.

The laboratory research method is a modification of the research conducted by Altug et al. (2012). The water sample that has arrived at the laboratory was subjected to serial dilution from 10-0 $10^{-5}$ using $\mathrm{NaCl}$. The bacterial growth media used were TCBS (Thiosulfate-Citrate-Bile Salts-Sucrose) and Mc. Conkey agar. TCBS agar medium to identify V. cholerae. 0.2 cc sample was taken which had been diluted and poured into a petri dish containing TCBS and incubated at $35^{\circ} \mathrm{C}$ for $24-48$ h. V. cholerae bacteria that have grown are then taken from the colony with a toothpick and placed on a glass object and then dripped with $V$. cholerae anti-sera. If there is agglutination, we make sure that it is positive for $V$. cholerae.

Mc. Conkey agar is a selectively isolate Gramnegative agar and is a differential medium for isolating bacteria. Samples that have been diluted as much as 0.1 were poured into petri agar Mc. Conkey, incubation at $35^{\circ} \mathrm{C}$ for $24-48 \mathrm{~h}$. To identify Shigella and Salmonella typhi bacteria, the bacterial colonies were taken and then dripped with anti-sera. Shigella and S. typhi bacteria were characterized by the occurrence of agglutination from each colony. Morphological identification was based on the EOC 1669 manual published by the World Health Organization in 2003 and the Basic Technique Guidelines for Health Laboratory, Ed. 2. Standard D-2 regulates the ballast water content that may be discharged into the waters (Table 1.).

\section{Results and Discussion}

The results showed that some of the ship's ballast water contained various types of harmful pathogenic bacteria such as V. cholerae, E. coli, and 
intestinal enterococci, the presence of which has been regulated in the BMW convention. In addition to these three types of bacteria, ballast water samples also contained various other types of bacteria such as S. typhi, Shigella desenteriae, Klebsiella, Staphylococcus epidermidis, Bacillus subtilis, and Actinobacteria (Figure 2.). The content of the most types of bacteria was found in the $M$ vessel tank, i.e., there were 6 types of bacteria from five ballast water samples taken from different tanks in 1 vessel. The bacteria content of $V$. cholerae and $E$. coli in the ballast water of ship $\mathrm{M}$ also had the highest number compared to other vessels, i.e., 15.000 CFU.100 ml-1 and 13.000 CFU.100 $\mathrm{ml}^{-1}$. In addition, the ballast water of ship $\mathrm{M}$ also contains bacteria enterococci as much as 7.000 CFU.100 $\mathrm{ml}^{-1}$, where this type of bacteria is not found in the ballast water of other ships. The ballast water on the KMOA ship from 2 different tanks did not find 10 types of bacteria as found in the ballast water of other ships.

Table 1. BMW Convention: Standard D-2

\begin{tabular}{|c|c|}
\hline Category & IMO Standart \\
\hline 50 my (Zooplankton) & $<10$ off per $\mathrm{m}^{3}$ \\
\hline 10-50 my (Phytoplankton) & $<10$ Off per $\mathrm{m}^{3}$ \\
\hline Bacteria & \\
\hline Toxicogenic V. cholerae & $<1$ cfu.100 ml-1 \\
\hline E. coli & $<250$ cfu.100 ml-1 \\
\hline Intestinal enterococci & $<100$ cfu.100 ml-1 \\
\hline
\end{tabular}

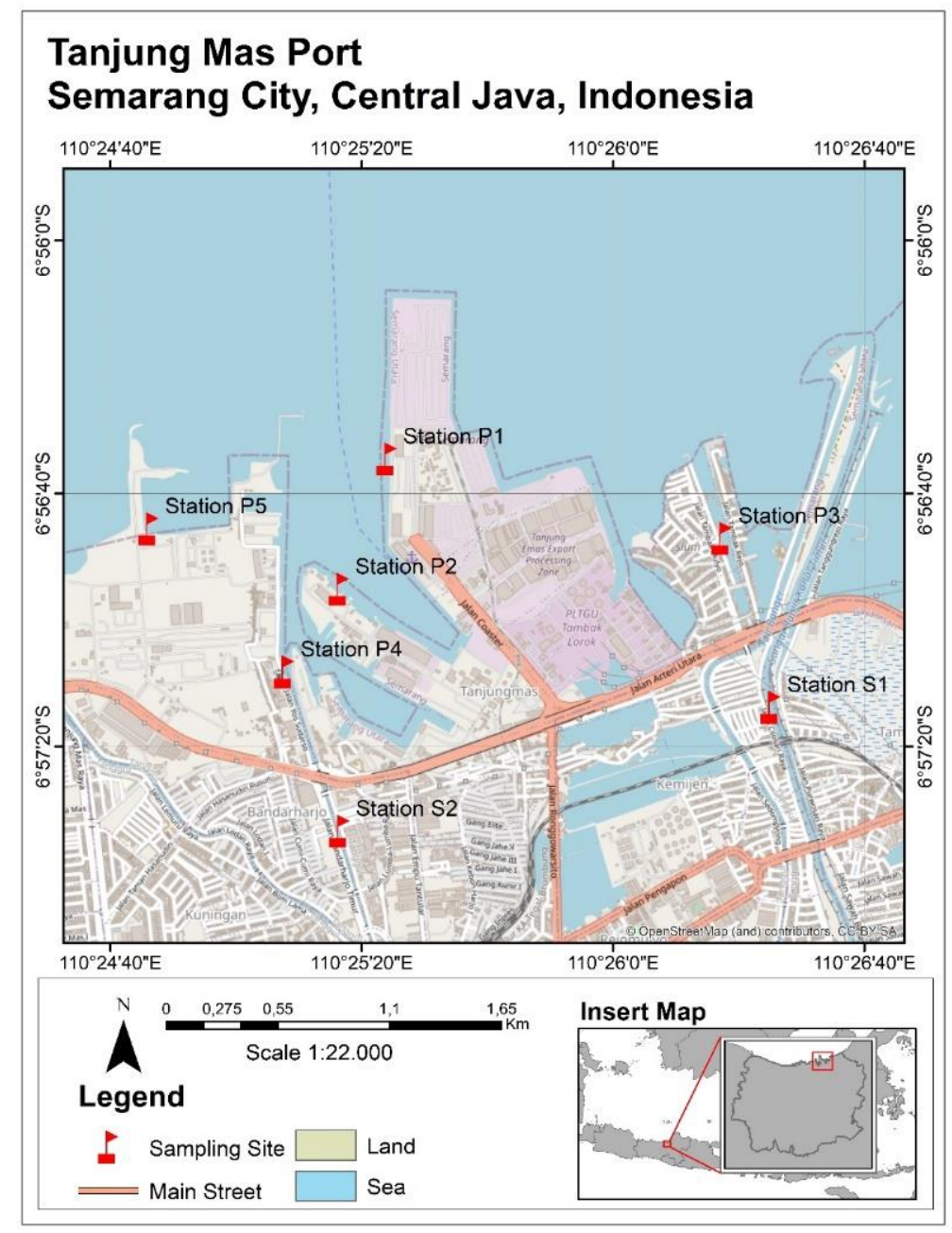

Figure 1. Study site of Tanjung Emas Port, Semarang, Indonesia 
Based on regulations from the International Maritime Organization (IMO) and the United States Coast Guard, ballast water that will be discharged into the environment must be threatened first (IMO, 2016; US Coast Guard, 2012). Treatment can be in the form of chemicals, production of reactive molecules, e.g. by Electrochlorination (EC) seawater, ultra-violet (UV) radiation, ozone, deoxygenation and heating (Goncalves and Gagnon, 2012). The standard threshold (Regulation D-2, Ballast Water Performance Standard 2002) allowed for the content of 3 types of main indicator bacteria, i.e., for ballast water a maximum of 1 CFU.100 $\mathrm{ml}^{-1}$ for $V$. cholerae, 250 CFU.100 ml-1 for E. coli, and 100 CFU.100 ml-1 for enterococci. In this study, the content of pathogenic bacteria V. cholerae in KVOG, KMPS, and M vessels exceeded the permissible threshold. Several studies have shown that besides bacteria there are several other organisms that can survive in ballast water tanks such as plant and animal species including fish. These organisms live in the water column or in sediments at the bottom of tanks (Medcof, 1975; Williams et al., 1988; Locke et al., 1991; Hallegraeff and Bolch, 1991, Carlton and Geller 1993; Gollasch et al., 2002).

The ballast water on the ship is taken from several water areas in Indonesia, where the ship is loading and unloading passengers and container. This causes the need for a treatment before the ballast water is discharged into the waters. Thus there is the potential for the spread of pathogenic organisms and invasive species from one waters to another. According to the BMW convention there are some exceptions to the discharge of ballast water without prior treatment, i.e., 1) ballast water uptake or discharge is needed for ensuring the safety of a ship in emergency situations; 2) accidental discharge results from damage to a ship or its equipment; 3) uptake or discharge of ballast water is used to avoid or minimize pollution incidents; 4) uptake and discharge of the same ballast water is conducted on the high seas; or 5) uptake and discharge occurs at the same location (Gollasch and David 2012, David et al., 2013b), provided no mixing occurs with other locations.

Water samples taken from several waters around the Tanjung Emas area, Semarang contain several types of bacteria such as those in ship ballast water samples. The highest type of bacteria $V$. cholerae was found in water samples P4.1 with a total of 2.600 CFU. $100 \mathrm{ml}^{-1}$, then for the highest type of bacteria $E$. coli found in water samples P2.1 and P3.1 with a total of $2.700 \mathrm{CFU} .100 \mathrm{ml}^{-1}$, while for the highest bacteria enterococci were found in water sample P4.1 (Figure 3). In addition to the 3 bacteria that became the main indicators in this study, 5 other types of bacteria were also found, i.e., S. typhi, S. desenteriae, Klebsiella, S. epidermidis, and B. subtilis as also found in the ship ballast water samples. However, Actinobacter was not found at all in the 5 waters that had been sampled around the Tanjung Emas waters area, Semarang.

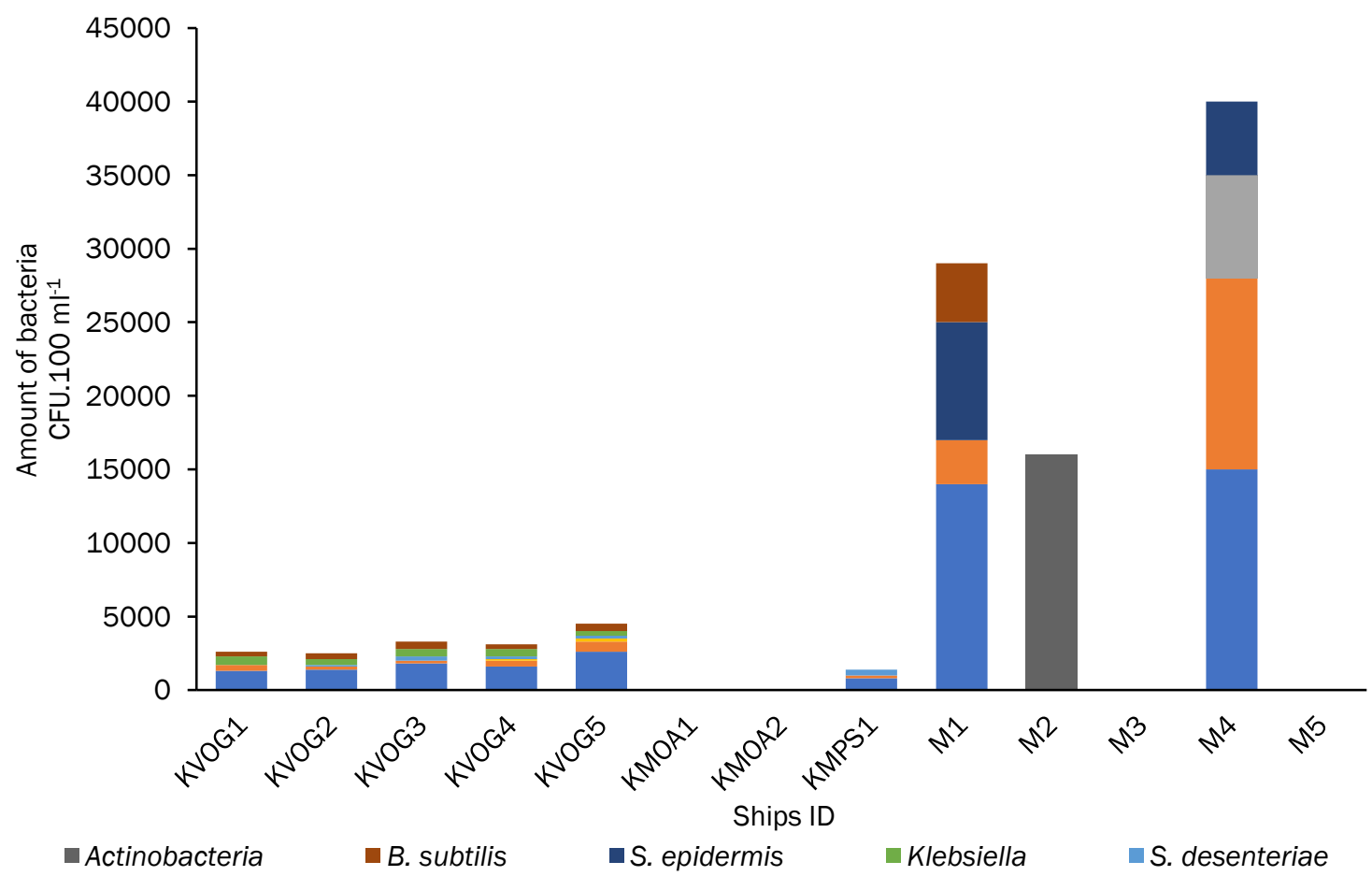

Figure 2. Bacterial content from ballast water Note: CFU (Colony Forming Unit's) 


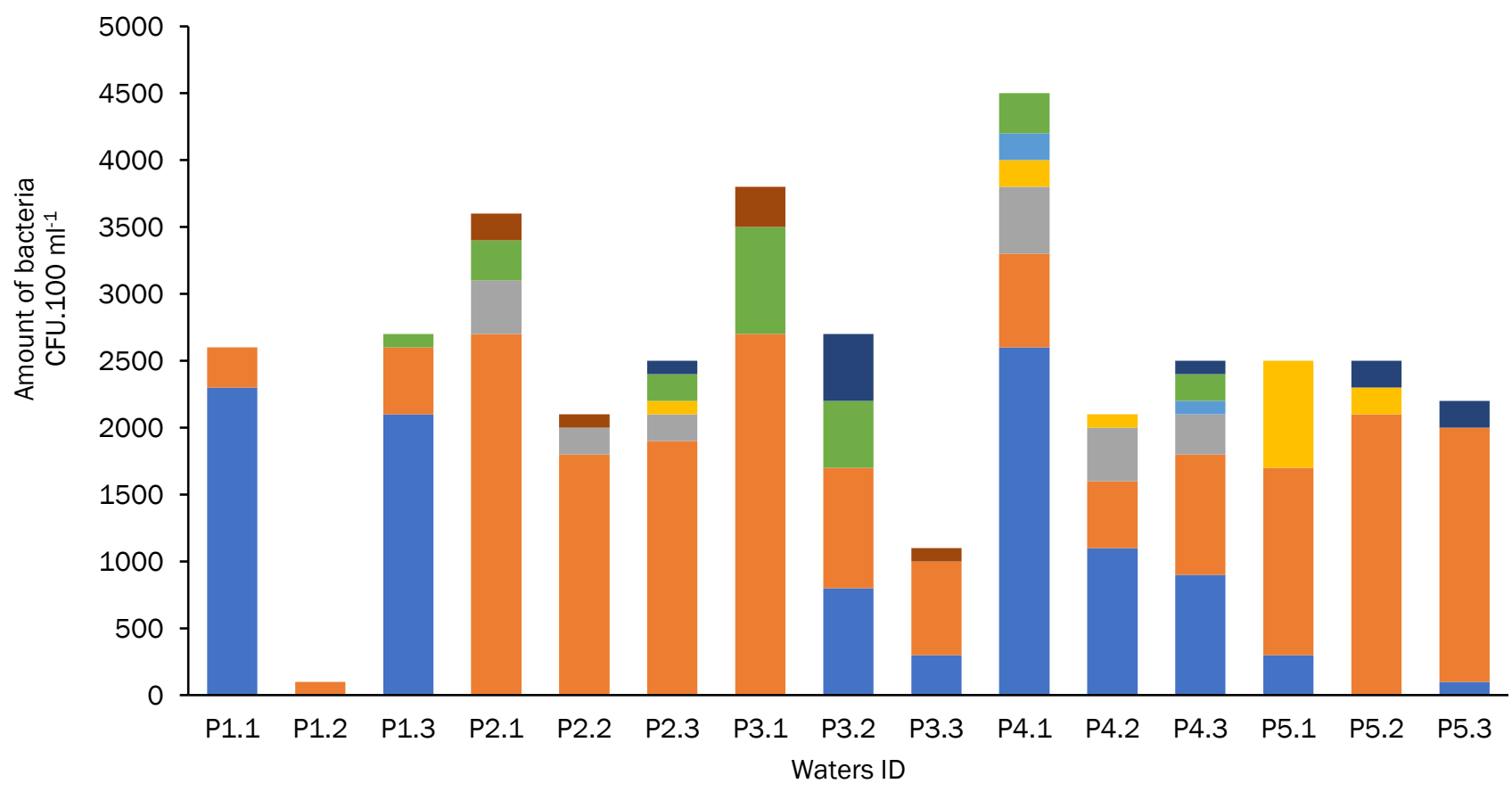

$\square$ Actinobacteria $\square$ B. subtilis $\backsim$ S. epidermis $\square$ Klebsiella $\square$ S. desenteriae $\square$ S. typhii $\square$ Enterococci $\square$ E. coli $\square$ V. cholerae

Figure 3. Bacterial content from Tanjung Emas Waters

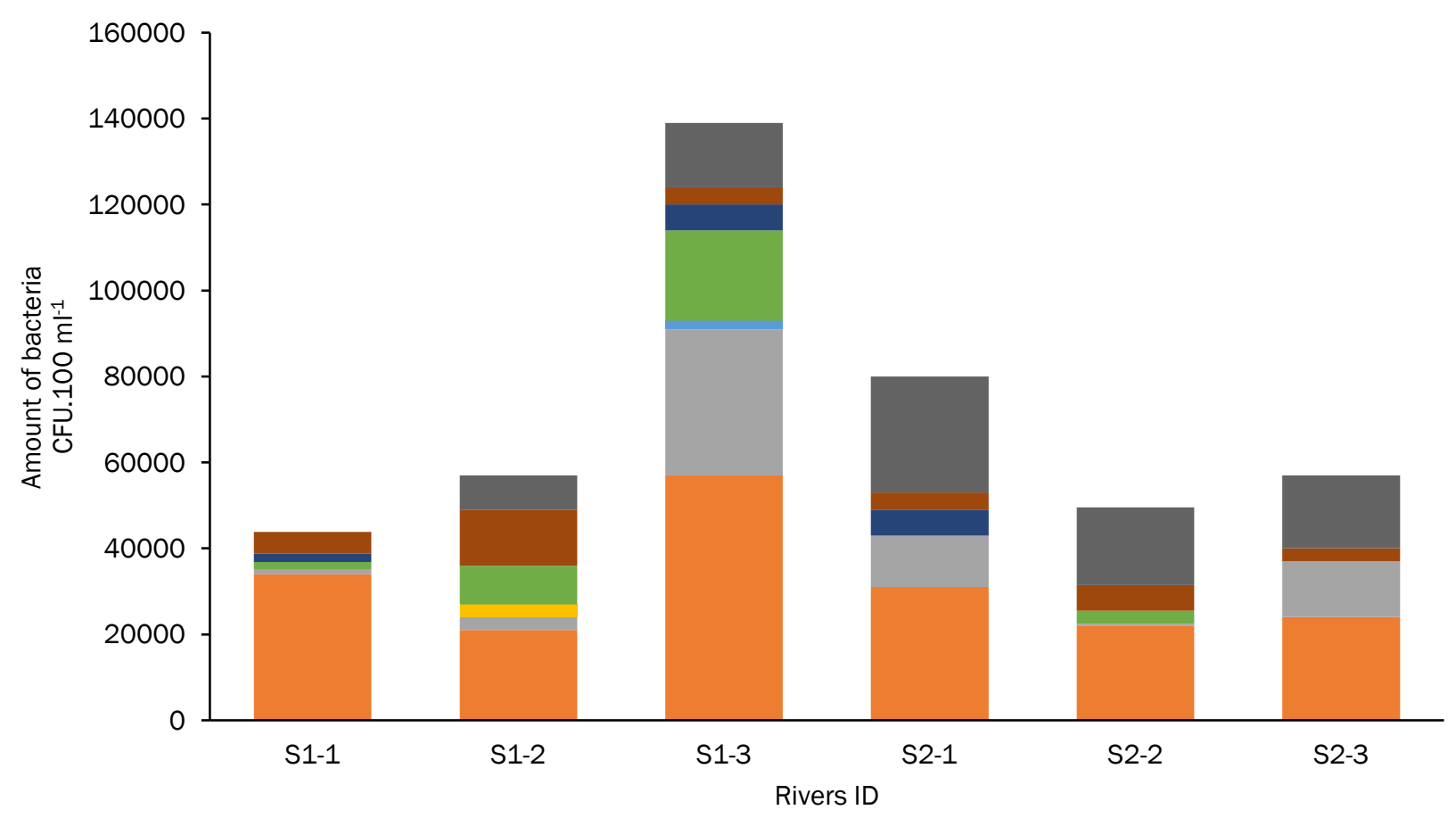

$\square$ Actinobacteria $\square$ B. subtilis $\backsim$ S. epidermis $\backsim$ Klebsiella $\backsim$ S. desenteriae $\backsim$ S. typhii $\square$ Enterococci $\square$ E. coli $\square$ V. cholerae

Figure 4. Bacterial content from Banger River (S1) and Baru River (S2)

Water samples taken from the Banger River and the Baru River contained several types of bacteria, namely $E$. coli, enterococci, S. typhii, S. desenteriae, Klebsiella, S. epidermidis, B. subtilis, and Actinobacteria (Figure 4). The highest bacterial content of $E$. coli and enterococci was found in the 
Banger River (S1-3) with a total of 57.000 CFU.100 $\mathrm{ml}^{-1}$ and 34.000 CFU.100 $\mathrm{ml}^{-1}$. While the bacteria $V$. cholerae was not found in the two rivers.

Samples taken from rivers that empty into the sea that fall within the predicted radius of distribution of ballast water discharge from ships, do not contain $V$. cholerae bacteria, so that the water from the river did not contribute to the presence of $V$. cholerae bacteria in port waters. The bacteria do not originate from rivers that empties into the sea, but from ship ballast water discharge. Samples from rivers contain significant amounts of $E$. coli and enterococci bacteria. That $V$. cholerae bacteria originating from ship ballast water affects the presence of $V$. cholerae bacteria in PTES waters.

The BWM Convention has been promulgated, so it is legally binding on all IMO member countries including Indonesia. So that ships that stop in Indonesia must meet the provisions of the BWM Convention standard D-2. Indonesia needs to prepare laws and regulations which are derivatives of the BWM Convention and socialize the BWM Convention and other laws and regulations to shipping companies and ship crews. Indonesia has ratified the BWM Convention on November 24, 2015, which means the BWM Convention has become a positive law that applies in Indonesia, with the issuance of Presidential Regulation (Perpres) Number 132 of 2015 concerning Ratification of the International Convention for the Control and Management of Ships' Ballast Water and Sediments (BWM).

\section{Conclusion}

The results show that ballast from the ships (KVOG, KMPS, and M) contains pathogenic bacteria: V. cholerae, E. coli, enterococci, S. typhii, S. desenteriae, Klebsiella, S. epidermidis, B. subtilis, and Actinobacteria. V. cholerae, E. coli, and enterococci bacteria present in ballast water levels exceed the BWM Convention threshold, so the ballast water must be treated before being disposed of.

\section{Acknowledgement}

Thank you to all parties from the Port Authority (KSOP) Class I Tanjung Emas Semarang Offices for assisting in licensing arrangements. Thank you also to the team from Magister Marine Science, i.e., Nenik Kholilah, Amelia Cahya Anggelina, and Galank Fad'qul Janarkho who helped during the research process.

\section{References}

Altug, G., Gurun, S., Cardak, M., Ciftci, P.S. \& Kalkan, S. 2012. The occurrence of pathogenic bacteria in some ships' ballast water incoming from various marine regions to the Sea of Marmara, Turkey. Mar. Environ. Res., 81: 35-42. https://doi.org/10.1016/j.marenvres.2012.0 8.005 .

Burkholder, J.M., Hallegraeff, G.M., Melia, G., Cohen, A., Bowers, H.A., Oldach, D.W., Parrow, M.W., Sullivan, M.J., Zimba, P.V., Allen, E.H. \& Kinder, C.A. 2007. Phytoplankton and bacterial assemblages in ballast water of U.S. Military ships as a function of port of origin, voyage time, and ocean exchange practices. Harmful Algae, 6(4): 486-518. https://doi.org/10.1016/j.hal. 2006.11.006.

BWM Convention. 2021. Class NK. English. https://www.classnk.or.jp/hp/en/activities/stat utory/ballastwater/index.html. Accessed: 19 September 2021.

Carlton, J.T. \& Geller, J.B. 1993a. Ecological roulette: the global transport of nonindigenous marine organisms. Science. 261: 78-82. https://doi. org/10.1126/science.261.5117.78

Carlton, J.T. 2001. Introduced species in U.S. coastal waters: environmental impacts and management priorities. Pew Oceans Commission, Arlington.

Cohen, N.J., Slaten, D.D., Marano, N., Tappero, J.W., Wellman, M., Albert, R.J., Hill, V.R., Espey, D., Handzel, T., Henry, A. \& Tauxe, R.V. 2012. Preventing Maritime Transfer of Toxigenic Vibrio cholerae. Emerg. Infect. Dis., 18(10): 16801682. https://doi.org/10.3201/eid1810.1206 76.

David, M. \& Gollasch, S. 2015. Introduction. In David M, Gollasch S (eds) Global Maritime Transport and Ballast Water Management - Issues and Solutions. Invading Nature. Springer Series in Invasion Ecology 8, Springer Science + Business Media, Dordrecht, The Netherlands. 306 pp.

David, M. 2015. Vessels and Ballast Water. In David M, Gollasch S (eds) Global Maritime Transport and Ballast Water Management - Issues and Solutions. Invading Nature. Springer Series in Invasion Ecology 8, Springer Science + Business Media, Dordrecht, The Netherlands. 306 pp.

David, M., Gollasch, S. \& Pavliha, M. 2013b. Global ballast water management and the "same location" concept: a clear term or a clear issue?. Ecological Applications. 23(2): 331-338. https://doi.org/10.1890/12-0992.1.

Davidson, I.C. \& Simkanin, C. 2012. The biology of ballast water 25 years later. Biological 
Invasions. 14(1): 9-13. https://doi.org/10.10 07/s10530-011-0056-1.

Drake, L.A., Choi, K.H., Ruiz, G.M. \& Dobbs, F.C. 2001. Microbial inventories in the ballast water of ships arriving in Chesapeake Bay. Mar. Ecol. Prog. Ser., 233: 13-20. https://doi.org/10.33 54/meps233013.

El-Husna, I., Anggoro, S., Sunoko, H.R. \& Setiani, O. 2017. Impact of ballast water on environmental health. Adv. Sci. Lett., 23(3): 2432-2434. https://doi.org/10.1166/asl.2017.8689.

Emami, K., Askari, V., Ullrich, M., Mohinudeen, K., Anil, A.C., Khandeparker, L., Burgess, J.G. \& Mesbahi, E. 2012. Characterization of Bacteria in Ballast Water Using MALDI-TOF Mass Spectrometry. PLOS ONE. 7(6): e38515. https://doi.org/10.1371/journal.pone.0038515.

Gollasch, S. 1996. Untersuchungen des Arteintrages durch den internationalen Schiffsverkehr unter besonderer Berücksichtigung nichtheimischer Arten. Doctoral Dissertation (in German), Universitas Hamburg. Verlag Dr. Kovac, Hamburg.

Gollasch, S., Cangelosi, A. \& Peperzak, L. 2012. Testing of ballast water treatment systems performance regarding organism below 10 micron in minimun dimension. Ballast Water Opportunity. 1-25pp.

Gollasch, S., MacDonald, E., Belson, S., Botnen, H., Christensen, J.T., Hamer, J.P., Houvenaghel, G., Jelmert, A., Lucas, I.A.N., Masson, D. \& McCollin, T. 2002. Life in ballast tanks. In: Leppäkoski E, Gollasch S, Olenin S (eds) Invasive aquatic species of Europe: distribution, impacts and management. Kluwer Academic Publishers, Dordrecht, pp 217-231.

Goncalves, A.A. \& Gagnon, G.A. 2012. Recent technologies for ballast water treatment. Ozone: Science Engineering. 34(2): 174-195. https:// doi.org/10.1080/01919512.2012.663708.

Hallegraeff, G.M. \& Bolch, C.J. 1991. Transport of toxic dinoflagellate cysts via ship's ballast water. Mar. Poll. Bull., 22(1): 27-30. https://doi.org/ 10.1016/0025-326x(91)9044 1-t

Hayes, K.R. \& C. Sliwa. 2003. Identifying potential marine pests-a deductive approach applied to Australia. Mar. Poll. Bull., 46(1): 91-98. https:// doi.org/10.1016/s0025-326x(02)003 21-1.
IMO. 2021. Addressing invasive species in ships' ballast water - treaty amendments enter into force. English. https://www.imo.org/en/Media Centre/PressBriefings/Pages/21-BWM-Amend ments-EIF-.aspx.

International Maritime Organization (IMO), 2016. The BWM Convention and Its Guidelines. http://www.imo.org/blast/blastDataHelper.asp ?data_id=23765\&filename= 174(58).pdf.

Joachimsthal, E.L., Ivanov, V., Tay, S.T.L. \& Tay, J.H. 2004. Bacteriological examination of ballast water in Singapore Harbour by flow cytometry with FISH. Mar. Poll. Bull. 49(4): 334-343 https: //doi.org/10.1016/j.marpolbul.2004 .02. 036.

Locke, A., Reid, D.M., Sprules, W.G., Carlton, J.T. \& Van Leeuwen, H.C. 1991. Effectiveness of midocean exchange in controlling freshwater and coastal zooplankton in ballast water. Canadian Technical Report. Fish Aquat. Sci., 1822: 1-93.

Medcof, J.C. 1975. Living marine animals in a ships' ballast water. Proc. Natl. Shellfish Assoc., 65: 54-55.

Ojaveer, H., Olenin, S., Narščius, A., Florin, A.B., Ezhova, E., Gollasch, S., Jensen, K.R., Lehtiniemi, M., Minchin, D., Normant-Saremba, M. \& Strāke, S. 2016. Dynamics of biological invasions and pathways over time: a case study of a temperate coastal sea. Biol. Invasions, 19(3): 799-813. https://doi.org/10.1007/s105 30-016-13 16-x.

Putra, I.N.G., Puspitha, N.L.P.R., Suryaningtyas, E.W. \& Suryaningtyas, E.W. 2021. Spread beyond the border: Small Scale genetic structure of the introduced Banggai cardinalfish (Pterapogon kauderni) population in the Bali Strait. ILMU KELAUTAN: Indonesian Journal of Marine Sciences, 26 (3): 165-172 https://doi.org/ 10.14710 /ik.ijms.26.3.165-172

Ruiz, G.M., Fofonoff, P.W., Carlton, J.T., Wonham, M.J. \& Hines, A.H.. 2000. Invasion of coastal marine communities in North America: apparent patterns, processes, and biases. Ann. Rev. Ecol. Systematics. 31(1): 481-531. https://doi.org/ 10.1146/annurev.ecolsys.31.1.481.

Seiden, J.M., Way, C.J. \& Rivkin, R.B. 2011. Bacterial dynamics in ballast water during trans-oceanic voyages of bulk carriers: environmental controls. Mar. Ecol. Prog. Ser., 436: 145-159. https://doi. org/10.3354/meps09231.

United States Coast Guard, 2012. Standards for living organisms in ship's ballast water discharged in U.S. waters. Fed. Regist. 77 (57). 
ILMU KELAUTAN: Indonesian Journal of Marine Sciences March 2022 Vol 27(1):45-52

Vidas, D. \& Kostelac, M.M. 2011. Ballast Water and Alien Species: Regulating Global Transfers and Regional Consequences. The World Ocean in Globalisation. Leiden/Boston: Martinus Nijhoff Publishers/Brill. pp. 371-392. https://doi.org/ 10.1163/978 9004204225_022.
Williams, R.J., Griffiths, F.B., Van der Wal, E.J. \& Kelly, J. 1988. Cargo vessel ballast water as a vector for the transport of non-indigenous marine species. Estuar. Coast. Shelf Sci., 26(4): 409420. https://doi.org/10.1016/0272-7714(88) 90021-2. 